\title{
Editorial: Engineering societal issues - geotechnical and geoenvironmental perspectives
}

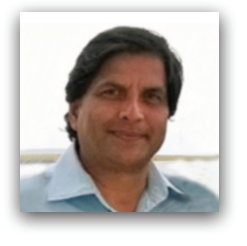

\section{Snehasis Tripathy}

Senior Lecturer, School of Engineering, Cardiff University, Cardiff, UK

Some of the issues that remain at the forefront of engineering challenges of the twenty first century are: the use of industrial wastes in various engineering applications by improving their engineering properties, ground improvement techniques as applicable to soft soil deposits, the efficiency of geo-storage systems, and the geologic sequestration of carbon dioxide to reduce greenhouse gas emissions. Research works in these areas have received significant attention from academics, researchers, industrial sector, and stakeholders.

Stabilisation and management of industrial sludge, tailings, and weak soils is required to reduce their negative impacts on humans and ecosystems (Fourie et al., 2007; Gray and Sotir, 1996; Prakash and Sridharan, 2009; Qian et al., 2006). Geo-materials involved in geo-storage systems experience complex cyclic loading. Repetitive reversal of boundary conditions can gradually deteriorate the properties of the geo-materials and affect performance of geostorage systems (Pasten and Santamarina, 2011). Similarly, interaction between the storage medium and carbon dioxide is expected to govern the storage capacity of geologic formations.

This issue of Environmental Geotechnics comprises seven papers. Four of the papers present investigations on the stabilisation of potential materials for various engineering applications, whereas two papers discuss the geo-energy topics associated with energy foundations and geologic carbon dioxide sequestration.

Sreedeep (2015) raises some key challenges that await for the geoenvironmental engineering community in terms of tackling various societal challenges as a result of degradation of the environment. The paper presents some interesting examples and explains how expertise of researchers in various fields of science and engineering can be brought together to solve pressing environmental problems.

Vega and McCartney (2015) present the effects of cyclic heatingcooling on the volume change and the pore-water pressure development in a silt. The thermo-mechanical response of the compacted silt at several stress states indicated that the volumetric and the pore-water pressure changes is strongly linked to the over consolidation ratio. The authors emphasise the significance of applying the measuring system corrections for interpreting experimental data.

Sludge from waste water treatment plants and fly ash from thermal power plants pose severe challenges for storage and disposal. Use of such materials in construction industries have been attempted by several researchers in the past but due to a large variation in the physical and chemical properties sometimes it is difficult to derive conclusions on the use of such materials. Disfani et al. (2015) presented a feasibility study of the stabilisation of biosolids using different additives. The geotechnical properties of stabilised biosolids improved significantly, which enhances the confidence level for the use of these materials in construction sectors.

Supercritical carbon dioxide injection in aquifer rocks and the influence of water evaporation and salt crystallisation is presented by Osselin et al. (2015). The authors present a one-dimensional numerical simulation to illustrate how poromechanical behaviour of structure subjected to constant flow of super critical carbon dioxide can be reliably assessed using the model.

Keykha et al. (2015) present some meticulously planned laboratory electrokinetic tests on a kaolinitic soil that was injected with bacteria, urea and calcium chloride. The technique (electro-biogrouting) showed calcium carbonate precipitation within the soil system, which in turn resulted in an increase in the shear strength of the clayey soil.

Becker and Vrettos (2015) present a ground improvement technique using enzymes. The enzyme-stabilised soil exhibited better resistance to the combined wind and water action, indicating the relevance of this ground improvement technique with additives other than conventional agents, such as fly ash, cement, bitumen, lime, among others.

The geotechnical characterisation of oil sand fine tailings in the context of surface deposition and its effect on the desaturation behaviour of the material is investigated by Owolagba and Azam (2015). The authors emphasise the significance of considering the suction-degree of saturation relationship and the shrinkage behaviour of such materials in analysing the dewatering process.

Some advanced geotechnical equipment and improved numerical models have been used in this issue of Environmental Geotechnics to produce high-quality data that describe some complex environmental problems. The list of references under each paper provide insight of the significant literature associated the works.

I sincerely hope readers will find the papers published in this issue of Environmental Geotechnics stimulating. 
Editorial: Engineering societal issues geotechnical and geoenvironmental perspectives Tripathy

\section{REFERENCES}

Becker A and Vrettos C (2015) Study on erosion stability enhancement of sands using enzymes. Environmental Geotechnics 2(5): 301-308, http://dx.doi.org/10.1680/ envgeo.13.00069.

Disfani MM, Arulrajah A, Maghoolpilehrood F, Bo MW and Narsilio GA (2015) Geotechnical characteristics of stabilised aged biosolids. Environmental Geotechnics 2(5): 269-279, http://dx.doi.org/10.1680/envgeo.13.00054.

Fourie AB, Johns DG and Jones CJFP (2007) Dewatering of mine tailings using electrokinetic geosynthetics. Canadian Geotechnical Journal 44(2): 160-172.

Gray DH and Sotir RB (1996) Biotechnical and Soil Bioengineering Slope Stabilization: A Practical Guide for Erosion Control. John Wiley \& Sons, New York, NY, USA.

Keykha H, Huat BBK and Asadi A (2015) Electro-biogrouting stabilisation of soft soil. Environmental Geotechnics 2(5): 292-300, http://dx.doi.org/10.1680/envgeo.13.00068.

Osselin F, Fabbri A, Fen-Chong T et al. (2015) Stress from $\mathrm{NaCl}$ crystallisation by carbon dioxide injection in aquifers.
Environmental Geotechnics 2(5): 280-291, http://dx.doi. org/10.1680/envgeo.13.00057.

Owolagba J and Azam S (2015) Geotechnical properties of centrifuged oil sand fine tailings. Environmental Geotechnics 2(5): 309-316, http://dx.doi.org/10.1680/envgeo.13.00079.

Pasten C and Santamarina JC (2011) Energy geo-storage analysis and geomechanical implications. KSCE Journal of Civil Engineering 15(4): 655-667.

Prakash K and Sridharan A (2009) Beneficial properties of coal ashes and effective solid waste management. Practical Periodical of Hazardous, Toxic and Waste Management 13(4): 239-248.

Qian G, Cao Y, Chui P and Tay J (2006) Utilization of MSWI fly ash for stabilization/solidification of industrial waste sludge. Journal of Hazardous Materials 129(1-3): 274-281.

Sreedeep S (2015) Vision ahead for environmental geotechnics. Environmental Geotechnics 2(5): 255-256, http://dx.doi. org/10.1680/envgeo.13.00101.

Vega A and McCartney JS (2015) Cyclic heating effects on thermal volume change of silt. Environmental Geotechnics 2(5): 257-268, http://dx.doi.org/10.1680/envgeo.13.00022. 